\title{
Eating Behaviours of Lactating Women Differ by Infant Age and Maternal BMI
}

\author{
Gizem Köse $^{1}$ (DD , Eftal Geçgil Demir ${ }^{2}$ iD
}

${ }^{1}$ Department of Nutrition and Dietetics, Faculty of Health Sciences, Acibadem Mehmet Ali Aydinlar University, Istanbul, Turkey

${ }^{2}$ Department of Nutrition and Dietetics, School of Health Sciences, Istanbul Medipol University, Istanbul, Turkey

Gizem KÖSE

Eftal GEÇGIL DEMIR

\begin{abstract}
Correspondence: Gizem Köse Department of Nutrition and Dietetics, Faculty of Health Sciences, Acibadem Mehmet Ali Aydinlar University, Atasehir, Istanbul, Turkey Phone: +905335603738
\end{abstract}

E-mail: drgizemkose@gmail.com

Received: 16 November 2021

Accepted: 19 January 2022

\begin{abstract}
Purpose: In lactation, women experience major changes in their lives as new internal and external demands for attention and care for themselves and the baby, also body mass index due to eating behaviours. Our aim was to define relationships between mindful eating and eating behaviours of breastfeeding mothers by baby's age and maternal BMI.
\end{abstract}

Methods: This cross-sectional study was conducted between October-November 2021 with 302 lactating mothers without chronic disease. Our study was approved by Ethics Committee of the Acibadem Mehmet Ali Aydinlar University. A questionnaire form that examined demographic data and Mindful Eating Questionnaire (MEQ-30) were applied. Anthropometric variables were reported by participants due to Covid-19 pandemic.

Results: Mean age of our participants was $30.6 \pm 4.2$ years. Mothers with obesity had lowest score in MEQ-30 $(p<0.001)$. Lactating mothers who were underweight had highest MEQ-30 score $(p<0.001)$. It was shown that lactating mothers have highest MEQ-30 score in the first 6 months, and MEQ-30 scores decreased as baby grows $(p<0.001)$.

Conclusion: Lactation period can be an appropriate time to bring about long-term changes in eating behavior. Healthcare professionals and teams can apply treatments focused on eating behavior and mindful eating for mothers with obesity in terms of their physical and emotional health, especially after the 6 th month of breastfeeding.

Keywords: lactation, body mass index, mindful eating, eating, emotional eating.

\section{Maternal BKi Ve Bebeğin Yaşı Laktasyon Dönemindeki Kadınların Yeme Davranışlarını Değiştirebilir ÖZET}

Amaç: Emzirme döneminde kadınlar, kendilerine bakma ve bebeğe bakım verme sürecinde yeni içsel ve dışsal taleplerle baş ederken, ayrıca yeme davranışlarındaki değişiklikler nedeniyle beden kütle indeksi (BKi) değerinde büyük değişiklikler yaşamaktadır. Bu araştırmadaki amaç, emziren annelerin beden kütle indeksi, yeme farkındalığı ve yeme davranışları arasındaki ilişkileri bebeğin yaşı ve maternal BKi çerçevesinde değerlendirmektir.

Gereç ve Yöntem: Bu kesitsel çalışma, Ekim-Kasım 2021 tarihleri arasında kronik hastalığı olmayan 302 emziren anne ile yapıımıştır. Çalışmamız Acıbadem Mehmet Ali Aydınlar Üniversitesi Etik Kurulu tarafından onaylanmış olup, katılımcılara demografik verileri inceleyen anket formu ve Yeme Farkındalığı Ölçeği (MEQ-30) uygulanmıştır. Covid-19 pandemisi nedeniyle antropometrik veriler katılımcılar tarafından rapor edilmiştir.

Bulgular: Katılımcılarımızın yaş ortalamas $30,6 \pm 4,2$ yıl olarak saptanmışıı. Obezitesi olan anneler yeme farkındalığı ölçeğinden (MEQ-30) diğer gruplara göre daha düşük puan almıştı. ( $p<0,001)$. Zayıf anneler en yüksek MEQ-30 skoruna sahip olduğu belirlenmiştir $(p<0,001)$. Emziren annelerin yeme farkındalığı düzeyinin ilk 6 ayda en yüksek olduğu, MEQ30 puanlarının bebek büyüdükçe düştüğü gösterilmiştir $(p<0,001)$.

Sonuç: Emzirme dönemi, yeme davranışında uzun vadeli değişiklikler meydana getirmek için uygun bir zaman dilimi olabilmektedir. Sağlık profesyonelleri ve ekipleri, özellikle emzirmenin 6. ayından sonra obezitesi olan annelere fiziksel ve duygusal sağlıkları açısından yeme davranışı ve farkındalığı odaklı tedaviler uygulayarak katkıda bulunabilir.

Anahtar Kelimeler: laktasyon, beden kütle indeksi, yeme davranışı, yeme, duygusal yeme. 
$\mathbf{P}$ regnancy is a strong predictor of long-term weight gain and obesity in women of childbearing age. Although adequate nutrition is important during pregnancy, excessive weight gain is not recommended, not just for physical (1) but also mental health (2). One of every two women with obesity cannot return to their prepregnancy weight after birth and encounter postpartum obesity. Gestational weight gain can be a risk of abdominal visceral fat increase and leads to the development of type 2 diabetes and cardiovascular disease later (2). Nutritional interventions aimed to reduce excessive body weight gain during pregnancy and postpartum obesity target changes in food intake as well as physical activity. Skouteris et al. (2010) emphasizes that psychological factors should have a more prominent role in intervention strategies in order to reduce effectively weight gain during pregnancy (3). Therefore, it is important to have an idea about underlying psychological mechanisms such as eating behaviors.

Eating behavior examines the mechanisms that direct the behavior in terms of how and under what conditions more people tend to eat (4). Studies clearly show that eating behaviors such as emotional, extrinsic, and restricted eating are associated with higher body mass index (BMI) and weight gain $(5,6)$. Emotional changes during pregnancy, stronger perception of external stimuli and food cravings support the hypothesis that eating behaviors play an important role in weight gain during pregnancy. Emotional states and associated eating behavior can take on different intensities at various stages of pregnancy. This process, which is relatively stable during pregnancy, tends to increase during breastfeeding (7). In a meta-analysis examining the relationship between weight gain during pregnancy, postpartum obesity and eating behaviors, it showed that intuitive eating may be associated with decreased weight gain and reduced postpartum obesity during pregnancy. But there was no relationship between food cravings, external, emotional, disinhibited, uncontrolled and careful eating and postpartum obesity (4).

Despite the problems of unhealthy eating behavior, community-based public health approaches to treatment and prevention are not sufficient. There is a particular need for binge and emotional eating interventions, given their prevalence and physical, psychological and social consequences (8). The breastfeeding period is an appropriate moment to bring about long-term changes in women's eating behavior. Our hypothesis was lactating mother's mindful eating levels may change by the baby grows. Therefore, in our study it was aimed to define relationships between body mass index, mindful eating and eating behaviors of breastfeeding mothers by baby's age.

\section{MATERIALS AND METHODS}

This study was conducted in Medipol Mega Hospital between February and July 2020 with 302 breastfeeding mothers without chronic disease. Mean age of the mothers is $30.6 \pm 4.2$ years. The approval of the study was obtained from Ethics Committee of the Acibadem Mehmet Ali Aydinlar University with the number of 2021-19/25.

\section{Data Collection}

A questionnaire form that examined demographic data and Mindful Eating Questionnaire (MEQ-30) were applied to breastfeeding mothers. In the questionnaire form, mother's age, education level, anthropometric information, and baby's monthly age were included. Body weight and height information were reported by the participants. Body mass index was then calculated by researchers by taking the ratio of weight in kilograms to height in square meters.

\section{Mindful Eating Questionnaire (MEQ-30)}

MEQ-30 was used to measure the mindful eating status of breastfeeding mothers. With the scale originally named Mindful Eating Questionnaire (MEQ), which was developed by Framson et al. in 2009, associations between eating behavior, mindfulness, and emotional state can be questioned (9). Mindful Eating Questionnaire adapted into Turkish by Kose et al. (2017), includes seven sub-scales as disinhibition (mindless eating), emotional eating, eating control, mindfulness, eating discipline, conscious nutrition and interference (10). The higher the score on the scale, the higher the mindful eating level is detected. The sub-scales provide more detailed information about the sample's eating behaviors. In original form of MEQ Cronbach's alfa, was 0.640 , Turkish form was 0.733 , in this study it was found as 0.781 .

Data were analyzed with IBM SPSS Statistics 22.0. In comparisons between groups, the Kruskal-Wallis test was used because the data did not show normal distribution. Chisquare test was used to compare two categorical groups. Significance was evaluated at the $p<0.05$ level. Height and body weight were measured, and Body Mass Index (BMI) was calculated using the formula: body weight $(\mathrm{kg}) / \mathrm{he}-$ ight $^{2}\left(\mathrm{~m}^{2}\right)$. The underweight group was excluded from the chi-square test due to the fact that the distribution between the groups was not found to be statistically suitable (expected value $=12.5 \%$ ) while classifying the BMI. 


\section{RESULTS}

The evaluation of the data obtained from this study was shared below. Mean age of breastfeeding mothers participating in the study was $30.6 \pm 4.2$ years (min. 20, max. 44), and their mean BMI was $24.5 \pm 4.5 \mathrm{~kg} / \mathrm{m}^{2}$ ( $\min .15 .1 \mathrm{~kg} /$ $\mathrm{m}^{2}$, max. $41.3 \mathrm{~kg} / \mathrm{m}^{2}$ ). When the BMl values of the participants were considered according to the classification of the World Health Organization (11), it was mostly (53.3\%) within normal BMI ranges.

Mother's mindful eating levels according to the BMI and their baby's age was shown in Table 1. Mothers with obesity had lowest scores in MEQ-30 ( $p<0.001)$ (Table 1). While the mothers with underweight BMI had the highest mindful eating score $(p<0.001)$, it was found that the mindful eating levels of the mothers was higher in the first 6 months of lactation $(p<0.05)$.
Participant's mindful eating and sub-scale scores according to BMI and baby's age were evaluated (Table 2). According to the BMI classification, mothers with underweight BMI had higher scores on the MEQ-30 and subscales compared to the other BMI groups, but only conscious nutrition was statistically significant $(p<0.001)$. When the mother's mindful eating levels were evaluated according to the age of the baby, it was seen that they have the highest MEQ-30 score in the first 6 months, and the mindful eating score decreases as the baby grows $(p<0.001)$ When the sub-scales were evaluated; disinhibition, eating control $(p<0.001)$, conscious nutrition and interference $(p<0.05)$ were high in mothers whose babies were 0-6 months old; emotional eating sub-scale was found to be higher in those with babies over 24 months $(p<0.001)$.

\begin{tabular}{|c|c|c|c|c|}
\hline & \multicolumn{2}{|c|}{ MEQ-30 Scores } & \multirow[b]{2}{*}{$X^{2}$} & \multirow[b]{2}{*}{$p$} \\
\hline & MEQ-30 $\geq 3$ & MEQ-30 <3 & & \\
\hline \multicolumn{5}{|c|}{ BMI } \\
\hline Underweight & $3.74 \pm 0.26(n=18)$ & $-(n=0)$ & \multirow{4}{*}{14.708} & \multirow{4}{*}{$0.001^{* *}$} \\
\hline Normal & $3.58 \pm 0.35(n=143)$ & $2.67 \pm 0.19(n=18)$ & & \\
\hline Overweight & $3.47 \pm 0.32(n=67)$ & $2.66 \pm 0.23(n=24)$ & & \\
\hline Obese & $3.34 \pm 0.31(n=21)$ & $2.53 \pm 0.22(n=11)$ & & \\
\hline \multicolumn{5}{|c|}{ Baby's age (monthly) } \\
\hline $0-6$ & $3.57 \pm 0.35(n=130)$ & $2.57 \pm 0.25(n=18)$ & \multirow{3}{*}{7.303} & \multirow{3}{*}{$0.026^{*}$} \\
\hline $6-12$ & $3.51 \pm 0.33(n=67)$ & $2.69 \pm 0.16(n=16)$ & & \\
\hline$\geq 12$ & $3.51 \pm 0.54(n=52)$ & $2.64 \pm 0.23(n=19)$ & & \\
\hline
\end{tabular}

Table 2. MEQ-30 scores and sub-scales according to BMI and baby's age

\begin{tabular}{|c|c|c|c|c|c|c|c|c|c|c|c|c|c|}
\hline & & \multicolumn{6}{|c|}{ BMI Classification of Mothers } & \multicolumn{6}{|c|}{ Baby's age (monthly) } \\
\hline & $\begin{array}{c}\text { Total } \\
(n=302)\end{array}$ & $\begin{array}{l}\text { Under- } \\
\text { weight } \\
(n=18)\end{array}$ & $\begin{array}{l}\text { Normal } \\
(n=161)\end{array}$ & $\begin{array}{c}\text { Pre } \\
\text { obese } \\
(n=91)\end{array}$ & $\begin{array}{l}\text { Obese } \\
(n=32)\end{array}$ & $x^{2}$ & $p$ & $\begin{array}{c}0-6 \\
(n=148)\end{array}$ & $\begin{array}{c}6-12 \\
(n=83)\end{array}$ & $\begin{array}{c}12-24 \\
(n=64)\end{array}$ & $\begin{array}{l}>24 \\
(n=7)\end{array}$ & $X^{2}$ & $p$ \\
\hline $\begin{array}{c}\text { MEQ- } \\
\mathbf{3 0}\end{array}$ & $3.4 \pm 0.5$ & $3.74 \pm 0.26$ & $3.47 \pm 0.44$ & $3.25 \pm 0.46$ & $3.06 \pm 0.48$ & 7.383 & 0.061 & $3.45 \pm 0.47$ & $3.35 \pm 0.44$ & $3.29 \pm 0.49$ & $3.14 \pm 0.59$ & 38.280 & $0.000^{* *}$ \\
\hline DI & $3.3 \pm 0.7$ & $3.93 \pm 0.55$ & $3.41 \pm 0.74$ & $3.15 \pm 0.73$ & $2.98 \pm 0.85$ & 7.200 & 0.066 & $3.43 \pm 0.73$ & $3.24 \pm 0.77$ & $3.19 \pm 0.76$ & $2.80 \pm 1.25$ & 23.851 & $0.000^{* *}$ \\
\hline EE & $3.4 \pm 1.1$ & $4.07 \pm 0.61$ & $3.56 \pm 0.99$ & $3.13 \pm 1.03$ & $2.64 \pm 1.04$ & 2.279 & 0.517 & $3.45 \pm 1.01$ & $3.30 \pm 1.11$ & $3.24 \pm 1.01$ & $3.48 \pm 1.35$ & 32.759 & $0.000^{* *}$ \\
\hline EC & $3.8 \pm 0.9$ & $4.45 \pm 0.67$ & $4.02 \pm 0.89$ & $3.46 \pm 0.97$ & $3.44 \pm 0.74$ & 5.785 & 0.123 & $3.90 \pm 0.92$ & $3.80 \pm 0.92$ & $3.70 \pm 0.99$ & $3.13 \pm 1.04$ & 37.268 & $0.000^{* *}$ \\
\hline MN & $3.3 \pm 0.4$ & $3.24 \pm 0.48$ & $3.20 \pm 0.36$ & $3.29 \pm 0.41$ & $3.26 \pm 0.48$ & 1.540 & 0.673 & $3.25 \pm 0.43$ & $3.26 \pm 0.40$ & $3.19 \pm 0.31$ & $3.22 \pm 0.29$ & 2.889 & 0.409 \\
\hline ED & $3.3 \pm 0.7$ & $3.44 \pm 0.44$ & $3.21 \pm 0.36$ & $3.27 \pm 0.71$ & $3.03 \pm 0.82$ & 6.245 & 0.100 & $3.23 \pm 0.78$ & $3.43 \pm 0.69$ & $3.44 \pm 0.64$ & $3.04 \pm 0.73$ & 7.131 & 0.068 \\
\hline $\mathrm{CN}$ & $3.3 \pm 0.5$ & $3.45 \pm 0.48$ & $3.32 \pm 0.52$ & $3.25 \pm 0.55$ & $3.07 \pm 0.48$ & 22.148 & $0.000^{* *}$ & $3.43 \pm 0.53$ & $3.19 \pm 0.47$ & $3.07 \pm 0.53$ & $3.20 \pm 0.46$ & 8.922 & $0.030^{*}$ \\
\hline IN & $3.6 \pm 0.8$ & $3.75 \pm 0.72$ & $3.71 \pm 0.76$ & $3.45 \pm 0.79$ & $3.22 \pm 0.96$ & 4.079 & 0.253 & $3.67 \pm 0.81$ & $3.51 \pm 0.78$ & $3.47 \pm 0.83$ & $3.35 \pm 0.69$ & 12.137 & $0.007^{*}$ \\
\hline
\end{tabular}

BMI: Body Mass Index, MEQ-30: Mindful Eating Questionnaire, DI: Disinhibition, EE: Emotional Eating, EC: Eating Control, MN: Mindfulness,

ED: Eating Discipline, CN: Conscious Nutrition, IN: Interference. ${ }^{*} \mathrm{p}<0.05,{ }^{* *} \mathrm{p}<0.001$. 
Table 3. Correlation of mother's age and BMI, baby's age with MEQ-30 and its sub-scales $(n=302)$

\begin{tabular}{|c|c|c|c|c|c|c|}
\hline & \multicolumn{2}{|c|}{ BMI } & \multicolumn{2}{c|}{ Mother's age } & \multicolumn{2}{c|}{ Baby's age } \\
\hline & $\boldsymbol{r}$ & $\boldsymbol{p}$ & $\boldsymbol{p}$ & $\boldsymbol{r}$ & -0.196 \\
\hline BMI & - & - & 0.136 & $0.018^{*}$ & $0.001^{* *}$ \\
\hline MEQ-30 & -0.333 & $0.000^{* *}$ & 0.072 & 0.214 & -0.172 & $0.003^{* *}$ \\
\hline DI & -0.253 & $0.000^{* *}$ & 0.098 & 0.091 & -0.169 & $0.003^{* *}$ \\
\hline EE & -0.312 & $0.000^{* *}$ & 0.078 & 0.177 & -0.092 & 0.110 \\
\hline EC & -0.366 & $0.000^{* *}$ & -0.127 & $0.027^{*}$ & -0.133 & $0.021^{*}$ \\
\hline MN & 0.070 & 0.225 & 0.011 & 0.856 & -0.059 & 0.303 \\
\hline ED & -0.126 & $0.028^{*}$ & 0.247 & $0.000^{* *}$ & 0.098 & 0.088 \\
\hline CN & -0.116 & $0.044^{*}$ & 0.040 & 0.490 & -0.279 & $0.000^{* *}$ \\
\hline IN & -0.197 & $0.001^{* *}$ & 0.023 & 0.689 & -0.115 & $0.046^{*}$ \\
\hline
\end{tabular}

BMI: Body Mass Index, MEQ-30: Mindful Eating Questionnaire, DI: Disinhibition, EE: Emotional Eating, EC: Eating Control, MN: Mindfulness,

ED: Eating Discipline, CN: Conscious Nutrition, IN: Interference. ${ }^{*} \mathrm{p}<0.05,{ }^{* *} \mathrm{p}<0.01$.

There were some correlations between $\mathrm{BMI}$ and age of mother, baby's age, and MEQ-30, sub-scale scores. As the baby's age increased, the mother's BMI decreased $(r=-0.196, p=0.001)$ (Table 3). The age of the baby and the mother's MEQ-30 ( $r=-0.172, p=0.003)$ score, and perspective from sub-scales; disinhibition $(r=-0.169, p=0.003)$, eating control $(r=0.133, p=0.021)$, conscious nutrition $(r=-0.279, p=0.000)$ and interference $(r=-0.115, p=0.046)$ factors were negatively correlated, but there were no correlations with emotional eating and eating discipline. As the mother's age increased, the BMI $(r=0.136, p=0.018)$ increases. When mindful eating and sub-scale scores were evaluated, mother's age was correlated negatively correlated with eating control $(p=0.027)$ and positively with eating discipline $(p=0.000)$. As mother's BMI increased, MEQ-30, disinhibition, emotional eating, eating control and interference factors decrease statistically significantly $(p=0.000)$. In addition, it was found to be negatively related to eating discipline and conscious nutrition $(p<0.05)$.

\section{DISCUSSION}

Lactating mothers' attitudes towards disinhibition, conscious nutrition, emotional and mindful eating subject to change by breastfeeding. Our hypothesis was accepted as mothers' mindful eating levels and eating behaviors changed, especially in the first 6 months of infants and after 2 years of age during breastfeeding.

In an intervention study with lactating women, obese lactating women had higher mindful eating scores (2). Weight management in lactation may positively affect food choices on healthy eating (7). In our study, mothers with obesity had lowest mindful eating scores and mothers were more mindful in eating for the first 6 months of the baby. And mindful eating scores were decreased as the babies were growing. Mothers who have 1-3-year-old children had greater nutritional knowledge and lost more weight (12). Mothers whose babies were 0-6 months old had more eating control and conscious in nutrition, also they were not affected negatively by interference. It seems to be that for the first months of baby, mothers were paying more attention and more mindful about eating.

Mothers that lactating between 3-15 months, described breastfeeding as 'satisfactory' (13), having a relationship with baby can prevent emotional eating (14). Emotional eating can predict postpartum weight retention (2). Positive emotional and social changes during lactation provides healthy eating choices and behaviors (15). Emotional eating may be prevented by intuitive eating in the first year of lactation (16). In this study, emotional eating, mindfulness, conscious nutrition sub-scales, which decreased in the first year after birth, increased again after first year of lactation. Meanwhile, mindful eating scores continue to decrease. And also, mothers who had underweight and normal $\mathrm{BMI}$ more conscious in nutrition than overweight and obese ones. Adequate and balanced nutrition is important in the postpartum period as in every period of life. Conscious nutrition is at the forefront for adequate and balanced nutrition. Mindful eating and intuitive eating are similar in approach to postpartum eating behaviors (4) that is why studies with intuitive eating has been used in comparisons. But mothers with babies over 24 months could cope with more emotional eating. Prospective and interventional studies showed that disinhibition had no relations with postpartum weight loss 
$(2,16-17)$. On the contrary, we found that postpartum body weight had a negative correlation with disinhibition. And also, our participants' BMI increase was related to emotional eating, eating control and discipline, conscious nutrition, interference decrease that showed as high mindful eating scores. Body weight management in lactation can prevent emotional eating and lead to conscious and mindful eating.

Pregnancy has an effect on craving high fat food and as a consequence weight gain (18). In a study with lactating women, their eating behaviors was not affected by distraction (2). In a systematic review that lactation and postpartum weight changes were unclear (13). In a meta-analysis, significant associations found between body weight and eating behavior during pregnancy and the postpartum period (19), but a different meta-analysis showed that there were no relations between eating behaviors and postpartum weight (4). In the present study, when babies were growing, mothers' BMI were decreasing, but their mindful eating levels were on the wane, too. Mothers that had older babies had little control and conscious on eating or nutrition. And also, mothers' BMI can have a bidirectional effect on eating behaviors. Quansah et al. (2019) reported that intuitive eater mothers had lower postpartum weight (16). And in our study as expected, increased BMI had a negative effect on mindful eating. Understanding the reasons which eating behaviors change postpartum weight (gain or retention) can be helpful for a preventative or therapeutic approach (4). While there were statistically significant differences in sub-scales between the groups in the evaluation of the data of the participants, we couldn't find similar results in the correlation analyses. This may be because our research was not intervention research.

There are so many studies on pregnancy and eating behaviors (18). As far as we know, it was the first study about mindful eating in lactating mothers. Our study had some limitations as lack of information about body weight and mindful eating levels prior to pregnancy. Future studies can be made with previous information or have study in a prospective nature.

\section{CONCLUSION}

Lactation period can bring long-term changes in body weight and eating behaviors. In pre-pregnancy, during pregnancy and lactation periods, women should be educated about nutrition so they can be more conscious. In order for their physical and emotional health, especially after the 6th month of breastfeeding, healthcare team should recommend provide more trainings about weight management and eating behaviors that may change.

\section{DECLARATIONS}

\section{Funding}

This study received no specific funding.

\section{Conflicts of Interest}

No potential conflict of interest was reported by the authors.

\section{Ethics Approval}

The protocol of the study was approved by the Ethical Committee of the Acibadem Mehmet Ali Aydinlar University with the number of 2021-19/25.

\section{Availability of Data and Material}

All authors accept that data and material is available.

\section{Authors' Contribution}

All authors contributed to the design and implementation of the research, to the analysis of the results and to the writing of the manuscript.

\section{REFERENCES}

1. Dikmen HA, Çankaya S. Maternal obezitenin prenatal bağlanma üzerine etkisi. Acibadem Univ Saglik Bilim Derg. 2018;2:118-23. DOI: 10.31067/0.2018.1

2. Most J, Altazan, AD, Amant MS, et al. Increased energy intake after pregnancy determines postpartum weight retention in women with obesity. J Clin Endocrinol Metab. 2020;105:1601-11. DOI:10.1210/ clinem/dgz330

3. Skouteris $\mathrm{H}$, Hartley-Clark L, McCabe M, et al. Preventing excessive gestational weight gain: A systematic review of interventions. Obes Rev. 2010;11:757-68. DOI:10.1111/j.1467-789X.2010.00806.x

4. Bijlholt M, Van Uytsel $H$, Ameye $L$, et al. Eating behaviors in relation to gestational weight gain and postpartum weight retention: $A$ systematic review. Obes Rev. 202;21:1-18. DOI:10.1111/obr.13047

5. French SA, Mitchell NR, Finlayson G, et al. Questionnaire and laboratory measures of eating behavior: Associations with energy intake and $\mathrm{BMI}$ in a community sample of working adults. Appetite. 2014;72:50-8. DOI:10.1016/j.appet.2013.09.020

6. van Strien $\mathrm{T}$, Konttinen $\mathrm{H}$, Homberg $\mathrm{JR}$, et al. Emotional eating as a mediator between depression and weight gain. Appetite. 2016;100:216-24. DOI:10.1016/j.appet.2016.02.034

7. Mento C, Le Donne M, Crisafulli S, et al. BMI at early puerperium: Body image, eating attitudes and mood states. J Obstet Gynaecol. 2017;37:428-34. DOI:10.1080/01443615.2016.1250727

8. Beccia AL, Ruf A, Druker $S$, et al. Women's experiences with a mindful eating program for binge and emotional eating: $A$ qualitative investigation into the process of change. J Altern Complement Med. 2020;26:937-44. DOI: 10.1089/acm.2019.0318

9. Framson C, Kristal AR, Schenk JM, et al. Development and validation of the mindful eating questionnaire. J Am Diet Assoc. 2009;109:143944. DOI:10.1016/j.jada.2009.05.006 
10. Kose G, Tayfur M, Birincioglu I, et al. Adaptation Study of the Mindful Eating Questiionnare (MEQ) into Turkish. J Cogn Psychother. 2017;5:125-34. DOI:10.5455/jcbpr.250644

11. World Health Organization. Obesity and overweight. Last Modified April 1, 2020. Accessed January 9, 2021. https://www.who.int/ news-room/fact-sheets/detail/obesity-and-overweight.

12. Klohe-Lehman DM, Freeland-Graves J, Anderson ER, et al. Nutrition knowledge is associated with greater weight loss in obese and overweight low-income mothers. J Am Diet Assoc. 2006;106:65-75. DOI:10.1016/j.jada.2005.09.047

13. Fraser $A B$, Grimes DA. Effect of Lactation on Maternal Body Weight: A Systematic Review. Obstet Gynecol Surv. 2003;58:265-9. DOI:10.1097/01.OGX.0000058116.93935.61

14. Raynor M. Pregnancy and the puerperium: the social and psychological context. Psychiatry. 2006;5:1-4. DOI:10.1383/ psyt.2006.5.1.1

15. Phelan S, Phipps MG, Abrams B, et al. Does behavioral intervention in pregnancy reduce postpartum weight retention? Twelve-month outcomes of the Fit for Delivery randomized trial1-3. Am J Clin Nutr. 2014;99:302-11. DOI:10.3945/ajcn.113.070151

16. Quansah DY, Gilbert L, Gross J, et al. Intuitive eating is associated with improved health indicators at 1-year postpartum in women with gestational diabetes mellitus. J Health Psychol. 2019;1:1-17 DOI:10.1177/1359105319869814

17. Phelan S, Wing RR, Brannen A, et al. Does Partial Meal Replacement During Pregnancy Reduce 12-Month Postpartum Weight Retention? Obesity. 2019;27:226-36. DOI:10.1002/oby.22361

18. Blau LE, Orloff NC, Flammer A, et al. Food craving frequency mediates the relationship between emotional eating and excess weight gain in pregnancy. Eat Behav. 2018;31:120-4. DOI:10.1016/j. eatbeh.2018.09.004

19. Dalrymple KV, Flynn AC, Relph SA, et al. Lifestyle interventions in overweight and obese pregnant or postpartum women for postpartum weight management: A systematic review of the literature. Nutrients. 2018;10:1-26. DOI:10.3390/nu10111704 